encounter many of the problems described by Drs Harrison \& Clarke. In dealing with them we find the ideas of Tom F. Main, and his emphasis on the careful consideration of the community as a whole, especially helpful. We share with Wilfried R. Bion the experience that, given the proper setting, even very disturbed patients can develop a sense of responsibility to their group, to the hospital, and to society as a whole.

As we have to defend our general analytic approach continuously against many odds, we are grateful to Drs Harrison \& Clarke for their summary of the historical roots of the work we do. We certainly agree that the "lessons learned at Northfield remain relevant to the practice of psychiatry today".

HEDI HAFFNER

Institut für Psychoanalyse

Waffenplatzstrasse 36

Postfach 6906

CH-8023 Zürich

Switzerland

\section{Self-neglect in adult life}

SIR: I read with interest the recent case reports on self-neglect in adult life (Journal, August 1992, 161, 265-267). These two cases are not the only cases of squalor among younger patients. MacMillan \& Shaw (1966) noted this in their original series, and this issue has been debated more recently (Shah, 1991). It has been suggested that age is not important in the development of this syndrome (Shah, 1991). Frontal lobe dysfunction (with or without dementia) has been suggested to be associated with the syndrome (Orrell et al, 1989: Shah, 1992). It would be interesting to know if Drs Vostanis \& Dean have any evidence of frontal lobe dysfunction in either patient (particularly Case 1, who had the revised Weschler Adult Intelligence Scale test).

These patients can be managed through psychiatric services and the Mental Health Act when there is evidence of mental illness (Cybulska \& Rucinski, 1986; Mulroy \& Shah, 1992). However, up to $50 \%$ of these patients do not have psychiatric disorder (MacMillan \& Shaw, 1966; Clark et al, 1975). In such situations, Section 47 of the National Assistance Act 1948 could be used. Here the patient can be removed to a place of safety (usually a hospital bed) "if he is suffering from grave chronic disease or, being aged, infirm or physically incapacitated, is living in insanitary conditions and is unable to devote to himself and is not receiving from other persons proper care and attention". This act offers powers of placement but no powers of treatment. The local environmental health department can use other legislation to deal with squalor (Mulroy \& Shah, 1992). Section 83 of the Public Health Act 1936 (amended by Section 35 of the 1961 Act) suggests that if "filthy or verminous premises" exist, then notice can be served to the owners or occupiers of the property to clean up. If this is not complied with then the environmental health department can clean up. An adjunct to this is Section 84 of the Public Health Act 1936, whereupon "filthy and verminous persons" can be "deloused".

Prevention of damage by the Pest Act 1949 (Section 4) may be useful if there is evidence of infestation with rats and mice. This can be served upon owners and occupiers. The neighbours may be able to invoke the nuisance provision under Section 80 of the Environmental Protection Act 1990.

\footnotetext{
Clark, A., Manikar, G. \& Gray, I. (1975) Diogenes syndrome: a clinical study of gross neglect in old age. Lancet, $i, 366-368$.

Cybulska, E. \& Rucinski, J. (1986) Gross self neglect in old age. British Journal of Hospital Medicine, July, 21-24.

MACMillan, D. \& SHAW, P. (1966) Senile breakdown in standards of personal and environmental cleanliness. British Medical Journal, ii, 1032-1037.

Mulroy, R. \& Sнан, A. K. (1992) Indescribable squalor. Update, (in press).

Orrell, M., Sahakian, B. \& Bergmann, K. (1989) Self neglect and frontal lobe dysfunction. British Journal of Psychiatry, 155, 101-105.

Sнан, A.K. (1991) Senile squalor syndrome - a misnomer? Care of the Elderly, 3, 52.

(1992) Senile squalor syndrome: a small series. Care of the Elderly, 4, 299-300.
}

Academic Unit for Psychiatry of Old Age

Ajit Shah

St Vincent's Hospital Clinical School

Mont Park Hospital Campus

Private Bag No. 1

Rosanna

Victoria 3084

Australia

\section{The designation of black people in psychiatric} research

SIR: Anthropologically speaking, there are only three major ethnic divisions of Homo sapiens, namely the negroid, caucasoid and mongoloid races. Although the words 'negroid' and 'negro' are still used in anthropology, there has been a tendency to avoid their use elsewhere, as these terms have, principally thanks to American racism and the resultant civil rights movements, acquired a connotation of racial abuse. (Similar considerations apply to the term 
'mongoloid', which fell into disfavour in the context of the previous designation of Down's syndrome as 'mongolian idiocy'). I will therefore refer in this letter to black people.

We have no difficulty with the designation of black people who are nationals of West African countries. It is also easy to see that black people of West African extraction who are nationals of the Caribbean islands are Afro-Caribbeans, African-Caribbeans or, as some prefer to call them, West Indians (though this latter designation is less precise insofar as it necessarily includes Caribbean people of other racial backgrounds, including the indigenous peoples of those islands, such as the Caribs). How then do we designate black people, of West African or AfricanCaribbean parentage, who are born in the United Kingdom and carry UK passports?

It is clearly incorrect to refer to them as West Africans on the one hand, or as West Indians or African-Caribbeans on the other, any cultural identification with people of these backgrounds notwithstanding. I think that the findings of our research would be on firmer ground if we recognised that there are three distinct subgroups of West Africans and people of West African extraction: the West Africans themselves, the African-Caribbeans (or West Indians) and the Afro-Britons or AfricanBritons, this last group being black people who are UK nationals.

The tendency to lump all African-Caribbeans and African-Britons into one large group as 'West Indians' muddies the waters in our research, and we should aim for greater clarity in the use of these terms.

The Royal London Hospital

IKECHUKWU O. AZUONYE

St Clement's

$2 A$ Bow Road

London E3 4LL

\section{Episodic dyscontrol}

SIR: I read with interest the article by Lewin \& Sumners (Journal, August 1992, 161, 261-262) in which they reported a patient who developed episodic dyscontrol after a road-traffic accident and responded well to carbamazepine. Although they considered intermittent explosive disorder (DSMIII-R) as a differential diagnosis, I wonder why they did not mention organic mood disorder (DSM-IIIR). Since there was evidence of bilateral frontal and temporal lobe lesions in their patient and he suffered from depressive states, it seems likely that his episodic dyscontrol might be due to underlying organic mood disorder. Assuming that this was the case, it is less surprising that he responded well to carbamazepine.

Department of Psychiatry

TAKESHI TERAO

University of Occupational and Environmental Health Iseigaoka 1-1

Yahatanishi-ku

Kitakyushu 807

Japan

\section{Applying Roberts' framework}

SIR: Using the framework described by Roberts (Journal, September 1992, 161, 293-308) I should like to present a case to illustrate the origins of delusion.

Case report. A 38-year-old woman with no previous psychiatric history sustained a severe head injury, and nine months later developed a paranoid state. Computerised tomography scan initially revealed diffuse cerebral contusions, but later there was no focal abnormality. Her intelligence quotient decreased (WAIS-R full scale 87-97, NART 114) and frontal lobe dysfunction was indicated by disinhibition and impulsivity and findings on the Wisconsin Card Sorting Test of idiosyncratic reasoning and gross impairment of abstract thinking and shift of mental set.

The injury acted as a non-specific precipitant (stage 2). Eight months later the prodrome (stage 3) was characterised by complaints of persistent confusion and impaired memory which, together with a psychological response to the trauma, led to depression and weepiness and to her belief that her brain was abnormal and about to discharge a lot of electricity. This could be seen as a rational attempt to explain abnormal experiences, but was not successfully adaptive as she entered a highly anxious state with concerns that she had a deep vein thrombosis and was about to die of a pulmonary embolus. She repeatedly called out her GP and dialled 999, but failed to be reassured and came to believe that she was being badly treated by the medical profession. This mental set could have engendered further persecutory beliefs by influencing her interpretation of events (Garety, 1991; Fleminger, 1992) and by priming preattentive processes to bring potentially threatening stimuli to attention (Anscombe, 1987).

In stage 4 she reported that her telephone was making strange noises and that she had been cut off in the midst of calls. On being told by a British Telecom engineer that the fault was under investigation, she interpreted this as meaning that she was under investigation and became established in the belief that she was being bugged. This misinterpretation arose because of the heightened signifcance given to the word 'investigation', possibly because intentional priming of preattentive processes was bypassed (Anscombe, 1987) or may not have been recognised in the way that willed intentions may not be in patients with positive symptoms (Frith \& Done, 1988). This alone may have been sufficient for her to apply an improbable explanation, but that she did so implies a failure of hypothesis evaluation. Jumping to a conclusion (Garety, 1991) could reflect 